\title{
Legal Protection For Population and Civil Regestration Services in Order to Create Security and Comfort for Service Officers
}

\author{
Gandi Sitinjak ${ }^{1}$, Faisal Santiago ${ }^{2}$ \\ \{gandisitinjak@gmail.com ${ }^{1}$ \} \\ Faculty of Law, Universitas Borobudur ${ }^{1,2}$
}

\begin{abstract}
Legal protection of population services and civil records in the framework of security and comfort for leading service officers. Legal Protection must be given to every citizen, and become a fundamental right in service and not only service users or consumers to be protected, but also service personnel must beprotected in serving the public of the administrative needs of residence documents and civil records. This is necessary because the population and civil records office has the task of conducting local government affairs based on the principle of autonomy and auxiliary duties, for the sake of smoothness and comfort in the service of officers need to be protected for the sake of the law.
\end{abstract}

Keywords: Protection; Services; Officer

\section{Introduction}

The implementation of a good and satisfying service is the desire of everyone in fulfilling their desires, both in goods, services, and administration services. Public services regulated in Law no. 25 of 2009 stipulate good, cheap, easy, fast, and straightforward service and fulfill community satisfaction. Services that focus more on service users and less in terms of protection for service personnel who are at the forefront and have big risks. The spirit of service increases with a comfortable and conducive atmosphere with legal protection applied to service officers.

Service strategies and techniques are regulated both in the Dukcapil Law no. 23 of 2006 and its successor law, Law no. 24 of 2013 regarding population and civil registration, as well as other regulations governing improving the quality and quantity of services, have not been felt enough. The population administration information system that has been implemented and the online service techniques that have been applied are still not sufficient to meet community satisfaction. Service officers who need to be protected in carrying out service activities are crucial to improve the quality and quantity of services, services that are binding on rules and regulations that can be subject to sanctions for service officers indicated to slow down or add to requirements and other public complaints. The process and service journey is disrupted and make the slow services due to investigations and investigations carried out by the PPNS for population and civil registration against officers who receive reports from the public. Seeing the reality on the ground in adminduk (population administration) services, it becomes disturbed and there is no feeling of comfort and safety for service officers so that innovation 
should be created to run aground, this is due to the influence of binding rules that become a shackle in being creative in creating services that are coveted by adminduk service users. Protection for service officers, especially leading services, must be protected by law, so that services become harmonious and balanced in the eyes of the law is not only the law only protects service users or consumers but also protection for service officers. In making laws and regulations, the policymakers should in the formulation of draft laws on population and civil registration pay attention to the norms in the rules for the protection of officers in the field so that the rights and obligations of every citizen are accommodated and equal before the law. Population and civil registration services are an auxiliary task carried out by regional implementing work units in population and civil registration and are the most important task in meeting the community's need for ownership of population documents and civil records.

In the Law No. 25 of 2009 concerning Public Services. The principle of legal certainty ranks second out of 12 (twelve) principles, meaning that everything related to public service standards must have a clear and firm legal basis, including standard requirements.

\section{Problem Formulation}

1. How is the legal protection of bureaucratic officers in carrying out population and civil registration services?

2. Why do officials not exercise discretion in the service of population and civil registration?

\section{Research Method}

This type of research is normative empirical research, namely legal research to find applicable legal rules and go into the field, legal principles, accompanied by legal doctrines to answer legal issues to be faced. The approaching method used in this research is a qualitative approach with a descriptive analysis method which provides an overview and analyzes how the model of legal protection for the discretion of village-level officials in population and civil registration services. Qualitative research is a procedure that produces descriptive data in the form of oral and written as well as documentation from individuals and government bureaucracies.

\section{Discussion}

Population and civil registration services are getting better and of better quality in serving the community in meeting their needs for administrative documents, but the quality of service still has not reached what all people expect, it is improvements and improvements in services are still being carried out. Legal protection is one way to improve services, not only protection for consumers but also legal protection for officers nor service officials at the forefront who are full of problems in addition to people who always want to be served quickly, so it's not surprising that complaints and complaints often occur because the protection of consumers above the wind gets priority over the protection of officers or service officials. Complaints are often an obstacle for frontline service officers, settlement of complaints is sometimes following expectations and reality in the field, and service officers become victims of 
investigations and investigations carried out by PPNS assigned to the population and civil registration services, investigations and investigations are the last resort as long as they can be resolved in the form of fulfilling the wishes of the applicant and does not need to be appointed and investigated by making a BAP.

According to state administrative law, settlement is only sufficient for administrative settlement and not brought into the criminal realm. The time-consuming process of investigation and investigation results in disrupted services, officers feel uncomfortable and afraid in making decisions (discretion), let alone to be creative and innovate, even though problems that are not financially detrimental and can be resolved by fulfilling the wishes of the applicant but are still brought to the realm of criminal law.

Discretion is the action of officials in taking the necessary decisions in an emergency in solving concrete problems in the administration of government, where the rules are not regulated, there is a legal vacuum, it is unclear, incomplete, there is government stagnation (government administration law no. 30 of 2014, chap. 1 number 9).

Legal protection, according to Philipus M. Hadjon consists of:[1]

a. Preventive legal protection is protection that is carried out to prevent the crime from happening.

b. Repressive legal protection, in the form of taking action against perpetrators of crimes committed or carried out after the crime occurred.

Applications for residence documents and civil records that must be completed are not small, and problems that are often encountered include changes in family cards due to divorce, one of the requirements is to attach the old family card, while the old family card is taken away by the ex-husband, according to the rules of population and civil registration requirements, family card The old KK (Family Card) must be attached, and the community often does not meet these requirements, because the old KK no longer exists, this is beyond the ability of the applicant. While the service officers always adhere to the applicable rules, the important thing is that the documents are complete and ready to be processed, so that due to the KK problem, a person can delay his marriage for months, not to mention the doubts of service officers and the chief executive of the population and civil registration unit in exercise its authority in the form of discretion which has not been explicitly regulated in the form of regulations and legislation to make discretionary efforts in completing and completing services quickly and precisely. There are concerns from public service providers if they continue to serve the community while the requirements are not met. First, the fear of being reported as a criminal, it seems that the concern is far-fetched and inappropriate and even if there are objections from other parties to the action, it should be carried out through administrative efforts and not directly brought to the criminal arena. Second, worry about maladministration for violating procedures. It can be understood with a discretionary approach, so service actions are very appropriate and recommended.

According to state administrative law, issues and disputes in the service of population and civil registration are not always brought to the Administrative Court but can be resolved in a settlement to fulfill the needs of the applicant.

\section{Conclusion}

Government decisions are always considered valid and preventive protection is a policy principle that cannot be punished. Government policies cannot be criminalized if there are no elements of harming state finances and benefiting themselves or other parties. Implementation 
of these policies for public services. While the repressive legal protection is contained in Law No. 5 of 1986 and Perma No. 4 of 2015, which stipulates that the Administrative Court has the authority to receive, examine, and decide whether or not there is an element of authority abuse committed by government officials following government administration law. So that the PTUN has the authority to receive, examine, and decide before the indictment process in the district court.

\section{Aims and Goals}

With legal protection for government bureaucratic officers, the implementation of population and civil registration services can run smoothly, safely, and orderly in serving the community for the needs of population documents and civil registration. Legal protection is the inviolable human right of every person in the Dukcapil service to create innovation and creation in the development of all sectors of life for the welfare of society as a whole.

\section{References}

[1] M. Hadjon, Philipus. 2007. Perlindungan Hukum Bagi Rakyat Di Indonesia. Edisi Khusus, Cetakan Pertama. Surabaya: Penerbit Peradaban

[2] Abdussalam. 2020. HAM Dalam Proses Peradilan. Jakarta: PTIK.

[3] Ali, Ahmad dan Wiwie Heryani. 2012. Menjelajahi Kajian Empiris Terhadap Hukum. Jakarta: Kencana.

[4] Amiruddin dan Zainal Asikin. 2019. Pengantar Metode Penelitian Hukum. Depok: Rajawali Pers.

[5] Amirulloh, Muhamad, dkk. 2021. Perlindungan Hukum Bagi Karyawan Inventor Paten Di Indonesia. Bandung: CV. Keni Media.

[6] Purba, Jonlar. 2017. Penegakan Hukum Terhadap Tindak Pidana Bermotif Ringan Dengan Restorative Justice. Jakarta: Jala Permata Aksara.

[7] Salim dan Erlies Septiana Nurbani. 2013. Penerapan Teori Hukum Pada PenelitianTesis dan Disertasi. Jakarta: Rajawali Pers.

[8] Setiawan, Yudhi, dkk. 2017. Hukum Administrasi Pemerintahan. Depok: Rajawali Pers. 